\title{
The cholinergic system in rat testis is of non-neuronal origin
}

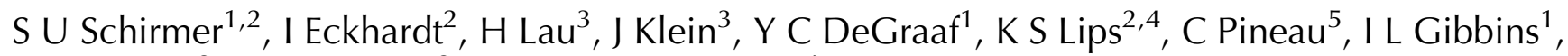 \\ W Kummer ${ }^{2}$, A Meinhardt ${ }^{2}$ and R V Haberberger ${ }^{1}$ \\ ${ }^{1}$ Anatomy and Histology, FMST, Flinders University, GPO Box 2100, 5001 Adelaide, South Australia, Australia, \\ ${ }^{2}$ Department of Anatomy and Cell Biology, Justus-Liebig University, Aulweg 123, 35385 Giessen, Germany, \\ ${ }^{3}$ Department of Pharmacology, College of Pharmacy, Goethe University, Max-von-Laue Strasse 9, 60438 Frankfurt, \\ Germany, ${ }^{4}$ Laboratory for Experimental Trauma Surgery, Justus-Liebig University, Kerkrader Strasse 9, 35394 Giessen, \\ Germany and ${ }^{5}$ Institut National de la Santé et de la Recherche Médicale, U625, Groupe d'étude de la reproduction \\ chez I'homme et les mammifères, Institut Fédératif de Recherche 140, Campus de Beaulieu, 35042 Rennes, France
}

Correspondence should be addressed to RV Haberberger; Email: rainer.haberberger@flinders.edu.au

\begin{abstract}
The cholinergic system consists of acetylcholine (ACh), its synthesising enzyme, choline acetyltransferase (CHAT), transporters such as the high-affinity choline transporter (SLC5A7; also known as ChT1), vesicular ACh transporter (SLC18A3; also known as VAChT), organic cation transporters (SLC22s; also known as OCTs), the nicotinic ACh receptors (CHRN; also known as nAChR) and muscarinic ACh receptors. The cholinergic system is not restricted to neurons but plays an important role in the structure and function of non-neuronal tissues such as epithelia and the immune system. Using molecular and immunohistochemical techniques, we show in this study that nonneuronal cells in the parenchyma of rat testis express mRNAs for Chat, Slc18a3, Slc5a7 and Slc22a2 as well as for the CHRN subunits in locations completely lacking any form of innervation, as demonstrated by the absence of protein gene product 9.5 labelling. We found differentially expressed mRNAs for eight $\alpha$ and three $\beta$ subunits of CHRN in testis. Expression of the $\alpha 7$-subunit of CHRN was widespread in spermatogonia, spermatocytes within seminiferous tubules as well as within Sertoli cells. Spermatogonia and spermatocytes also expressed the $\alpha 4$-subunit of CHRN. The presence of ACh in testicular parenchyma (TP), capsule and isolated germ cells could be demonstrated by HPLC. Taken together, our results reveal the presence of a non-neuronal cholinergic system in rat TP suggesting a potentially important role for non-neuronal $\mathrm{ACh}$ and its receptors in germ cell differentiation.

Reproduction (2011) 142 157-166
\end{abstract}

\section{Introduction}

The cholinergic system consists of acetylcholine (ACh), its synthesising enzymes, transporters and receptors. ACh is synthesised by choline acetyltransferase (CHAT). Ongoing ACh synthesis requires the uptake of choline into cholinergic cells via a high-affinity choline transporter (SLC5A7; also known as ChT1; Okuda et al. 2000). In neurons, ACh is transported into synaptic vesicles via the vesicular ACh transporter (SLC18A3; also known as VAChT; Erickson et al. 1996, Parsons 2000) and released via exocytosis upon stimulation. In addition, ACh release can occur through bidirectional transport of $\mathrm{ACh}$, utilising organic cation transporters (SLC22s; also known as OCTs) with SLC22A2 being the most likely candidate for non-neuronal transport (Wessler et al. 2001, Lips et al. 2005). ACh can stimulate five different G-protein-coupled muscarinic receptor subtypes (CHRMs, also known as mAChR; Nathanson 2008) and an unknown variety of ionotropic nicotinic ACh receptors (CHRN; also known as nAChR) with subtype-specific arrangements of nine $\alpha$ - and four $\beta$-subunits in mammals (Albuquerque et al. 2009). It is now known that the cholinergic system, traditionally associated with neurotransmission, is not restricted to neurons but plays an important role in the structure and function of non-neuronal tissues such as epithelia and the immune system (Fujii et al. 2008, Kummer et al. 2008, Wessler \& Kirkpatrick 2008). For example, in epithelia, CHRNs are involved both in maintaining the integrity of the epithelial layer and in the development of neoplastic changes (Grando et al. 2003, Grozio et al. 2007, Paleari et al. 2009).

Several observations indicate the presence of a cholinergic system within the mammalian testis: functional ACh receptors are found on male germ cells and Sertoli cells; mice lacking CHRN subtypes or with reduced ACh levels reveal reduced sperm motility (Borges et al. 2001, Bray et al. 2005); and high nicotine levels in the blood lead to reduced sperm production and fertility (Dwivedi \& Long 1989, Yamamoto et al. 1998). Published reports suggest that there is little, if any, 


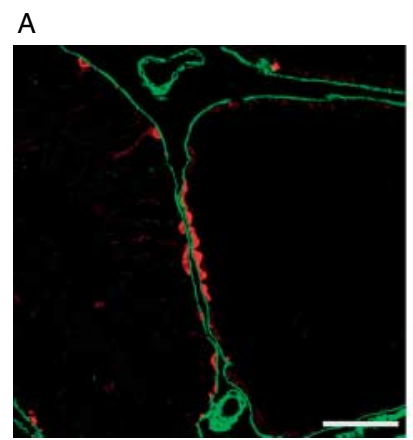

B

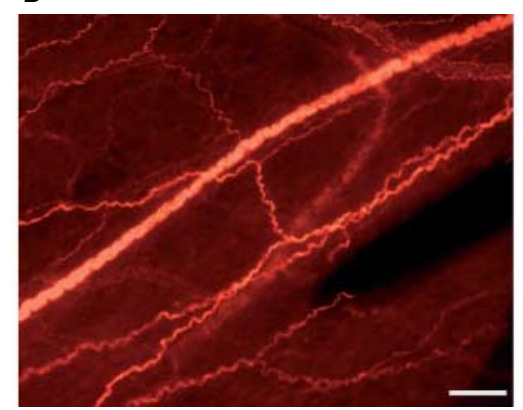

C

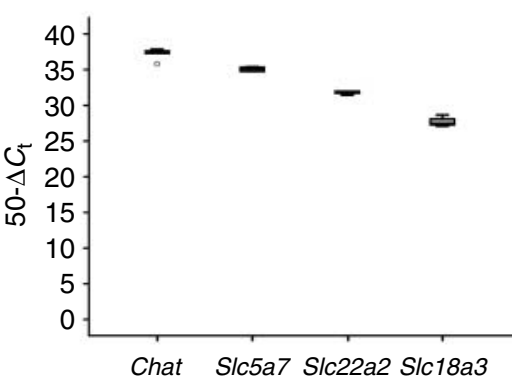

Figure 1 (A) Innervation within the testicular parenchyma (TP) was examined with an antibody against protein gene product 9.5 (PGP 9.5 , red). $\alpha$-smooth muscle actin antibody labels peritubular myoid cells and interstitial blood vessels (green). Nerve fibres were absent in rat TP, but PGP 9.5 appears to stain a spermatogonial subpopulation. Bar, $75 \mu \mathrm{m}$. (B) The mesostructures showed a dense innervation with PGP 9.5 positive nerve fibres and nerve fibre bundles. Bar, $100 \mu \mathrm{m}$. (C) Box plot showing the relative mRNA expression levels of choline acetyltransferase (Chat), highaffinity choline transporter (S/C5a7), vesicular ACh transporter (S/C18a3) and organic cation transporter 2 (S/c22a2) in TP. The $\Delta C_{\mathrm{T}}$ values were subtracted from 50 showing higher values with higher expression.

cholinergic innervation of most testicular tissue suggesting the presence of a non-neuronal cholinergic system. However, neither the sites of testicular ACh synthesis nor the cells targeted by locally synthesised $\mathrm{ACh}$ are known. Therefore, we have used molecular and immunohistochemical techniques to determine the levels of ACh, and the expression patterns of CHAT, SLC5A7, SLC18A3, SLC22A2 and CHRN subunits in rat testicular tissue.

\section{Results}

\section{The synthesising enzyme and the transporters of the cholinergic system are expressed in testicular parenchyma}

No protein gene product (PGP) 9.5 positive nerve fibres could be detected in the parenchyma of rat testes, whereas non-neuronal basal cells of seminiferous tubules showed PGP 9.5 immunoreactivity (IR; Fig. 1). In contrast to the parenchyma, the mesostructures that connect testis with epididymis and ductus deferens were densely supplied with PGP 9.5 positive nerve fibres (Fig. 1). However, PCR revealed significant expression of mRNA for Chat, Slc5a7, Slc18a3 and Slc22a2 in testicular parenchyma (TP). After removal of the testicular capsule (TC), the relative mRNA expression profiles in the parenchyma had a rank order of Chat $>$ Slc5a7>SIC22a2>Slc18a3 (Fig. 1 and Table 1).

We further determined the expression of mRNAs for cholinergic elements in isolated populations of testicular cells. Chat mRNA was localised in cells of the seminiferous tubules (Fig. 2). High or moderate expression levels of mRNA for Chat, Slc5a7, Slc18a3 and Slc22a2 occurred in pachytene spermatocytes, round spermatids and, except for Slc18a3, in residual bodies (Fig. 2). In contrast, no product corresponding to Chat, Slc5a7, Slc18a3 or Slc22a2 mRNA could be detected in Sertoli cells, peritubular cells and spermatogonia. Products corresponding to Chat and Slc5a7 were present in total RNA from isolated testicular macrophages (TM). A PCR product corresponding to Chat mRNA could be detected in Leydig cells (Fig. 2).

\section{CHAT and SLC5A7 proteins are present in seminiferous tubules}

IR for CHAT, SLC5A7, SLC22A2 and SLC18A3 was detected mainly in the seminiferous epithelium. CHAT-IR was detected also in endothelial cells of small interstitial arteries. The labelling was absent after pre-absorption with the corresponding antigen. Strong IR for CHAT and SLC5A7 was detected in spermatids and in some basal cells of the seminiferous tubules, presumably spermatogonia (Fig. 3). Similar cells were also positive for SLC18A3 (Fig. 3), while only barely detectable SLC18A3 labelling was present in

Table 1 Relative expression levels for CHRN subunits, and Chat, Slc5a7, Slc18a3 and Slc22a2 in testicular parenchyma.

\begin{tabular}{lcc}
\hline CHRN subunit & Samples $(n)$ & $\begin{array}{c}\text { Testicular parenchyma } \\
\text { (mean } \pm \text { s.D.) }\end{array}$ \\
\hline$\alpha 1$ & 3 & $30.1 \pm 0.17$ \\
$\alpha 2$ & 5 & $29.2 \pm 0.54$ \\
$\alpha 3$ & 5 & $28.9 \pm 0.92$ \\
$\alpha 4$ & 5 & $39.8 \pm 0.19$ \\
$\alpha 5$ & 3 & $33.5 \pm 0.42$ \\
$\alpha 6$ & 5 & $8.7 \pm 11.94^{*}$ \\
$\alpha 7$ & 3 & $34.6 \pm 0.55$ \\
$\alpha 9$ & 5 & $32.9 \pm 0.39$ \\
$\alpha 10$ & 3 & $29.0 \pm 0.94$ \\
$\beta 1$ & 3 & $34.8 \pm 0.40$ \\
$\beta 2$ & 3 & $35.8 \pm 0.68$ \\
$\beta 3$ & 3 & $33.9 \pm 0.19$ \\
$\beta 4$ & 5 & 0.0 \\
Slc22a2 & 3 & $31.8 \pm 0.28$ \\
Chat & 3 & $37.2 \pm 0.81$ \\
Slc5a7 & 7 & $35.0 \pm 0.30$ \\
Slc18a3 & 3 & $27.7 \pm 0.81$
\end{tabular}

The asterisk indicates the absence of mRNA in three out of five replicates, while the other two replicates revealed very weak expression. 


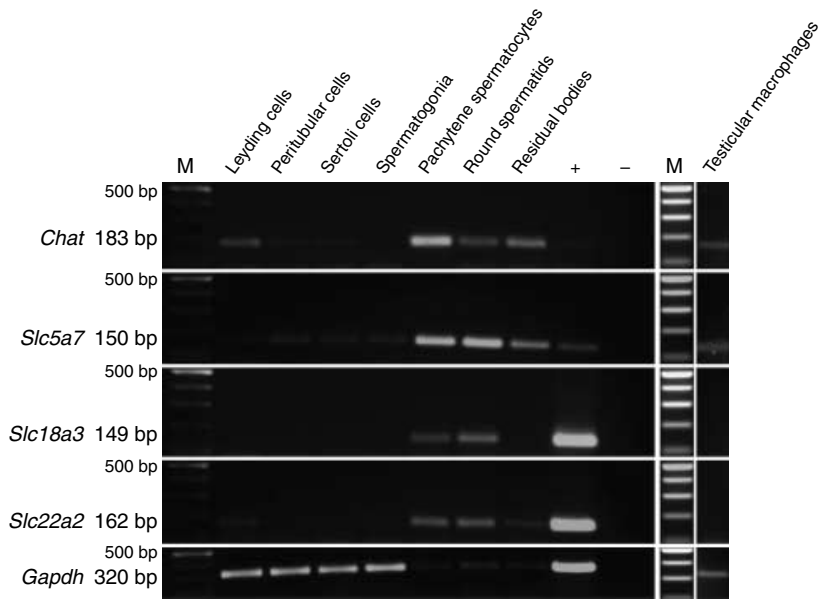

Figure 2 Ethidium bromide-stained agarose gels showing the PCR products for choline acetyltransferase (Chat, product length $183 \mathrm{bp}$ ), high-affinity choline transporter (S/C5a7, product length $150 \mathrm{bp}$ ), vesicular ACh transporter (S/C18a3, product length $149 \mathrm{bp}$ ) and organic cation transporter 2 (Slc22a2, product length $162 \mathrm{bp}$ ) in isolated cell populations as examined by RT-PCR. Gapdh (product length $320 \mathrm{bp}$ ) served as the reference gene. + , rat brain (positive control); -, water control (negative control) and $\mathrm{M}$, marker.

other cell types of the seminiferous epithelium (Fig. 3). SLC22A2 IR was visible in Leydig cell clustered in the interstitium, but not within the seminiferous tubules (Fig. 3).

\section{Multiple CHRN subunits are expressed in different cell types of the TP}

To determine potential targets of ACh in the testis, we first analysed the relative mRNA expression patterns of CHRN subunits in TP. In the parenchyma, mRNA for 11 out of 13 CHRN subunits, including the supposedly 'muscle

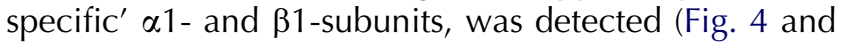
Table 1). The mRNAs for CHRN $\alpha 6$ - and $\beta 4$-subunits could not be detected in the TP but were present in the TC (Fig. 4). The highest levels of expression were observed for mRNA for $\alpha 4$-subunit followed by $\alpha 7-, \alpha 5-$ and $\alpha 9$ subunits and $\beta$-subunits 1-3 (Fig. 4 and Table 1).

\section{The mRNAs for the $\alpha 7$ - and $\alpha 4$-subunits of CHRN are expressed in the seminiferous tubule}

As mRNAs for $\alpha 4$ - and $\alpha 7$-subunits of CHRN were strongly expressed in the testis and $\alpha 7$-subunit of CHRN has been reported to be associated with sperm motility (Bray et al. 2005), we investigated the mRNA expression patterns of both subunits in isolated cell preparations. PCR products corresponding to mRNAs of both subunits were present in peritubular and Leydig cells, whereas Sertoli cells contained mRNA for the $\alpha 7-$, but not the $\alpha 4$-subunit of CHRN. Spermatogonia as well as pachytene spermatocytes expressed mRNAs for $\alpha 4$ - and $\alpha 7$-subunits; however, mRNA for $\alpha 7$-subunit could not be detected in later stage spermatocytes. The PCR product corresponding to mRNA for the $\alpha 7$-subunit was found in residual bodies, but not in round spermatids (Fig. 5). TM expressed mRNAs for both $\alpha 4$ - and $\alpha 7$-subunits (Fig. 5). Since subtype-specific CHRN antisera were not available (Herber et al. 2004, Moser et al. 2007), it was not possible to further analyse the distribution of receptor subunit proteins. However, in situ hybridisation localised mRNA for the $\alpha 7$-subunit of CHRN in pachytene spermatocytes (Fig. 6).

\section{ACh is present in testis}

ACh was measured in rat testis. Comparison of the ACh content in 16-day-old immature testes as well as in adult testes showed that ACh was present in all
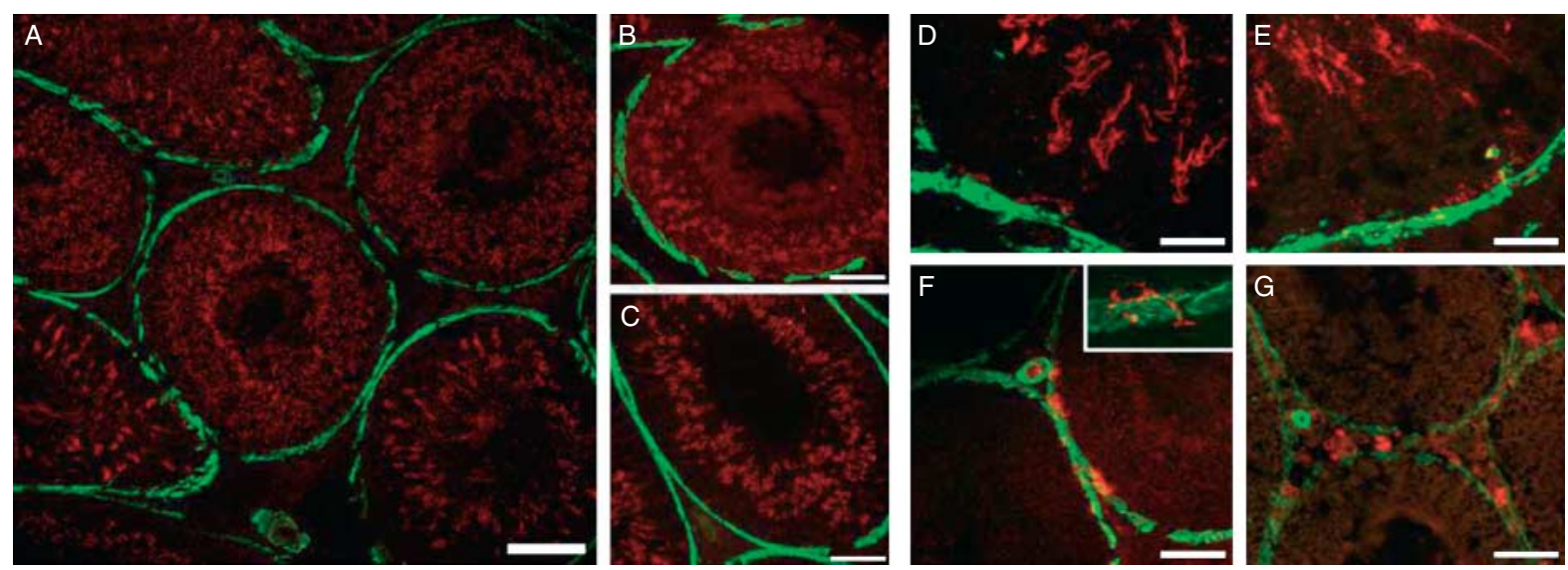

Figure 3 Multiple labelling immunohistochemistry. (A, B and D) Choline acetyltransferase (CHAT, in red), (C and E) high-affinity choline transporter (SLC5A7, in red), (F) vesicular acetylcholine transporter (SLC18A3, in red), (G) organic cation transporter 2 (SLC22A2). CHAT and SLC5A7 are present in spermatids (A-C), with CHAT-antiserum additionally staining round spermatids and some meiotic cells (D), while SLC18A3 is present in spermatogonia (F, inset). SLC22A2 is present in interstitial cells $(\mathrm{G})$. $\boldsymbol{\alpha}$-Smooth muscle actin was visualised with FITC-coupled antibody (green in A-G). Bars A, $100 \mu \mathrm{m} ; \mathrm{B}, \mathrm{C}, \mathrm{F}$ and $\mathrm{G}, 75 \mu \mathrm{m} ; \mathrm{D}$ and $\mathrm{E}, 20 \mu \mathrm{m}$. 

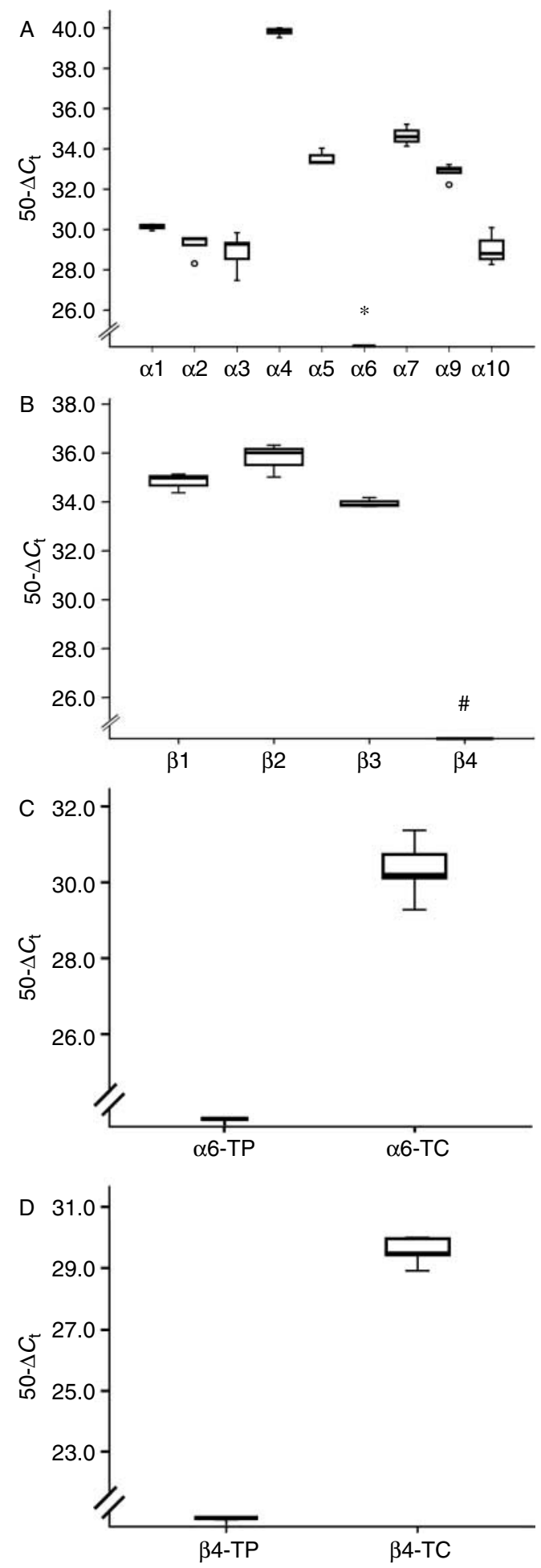

Figure 4 The mRNA expression level of the nicotinic ACh receptor (CHRN) subunits, $\alpha(A)$ and $\beta(B)$, in testicular parenchyma (TP) was determined by RT-qPCR. The asterisk indicates the absence of mRNA in three out of five replicates, while the other two replicates revealed very weak expression. \#, no mRNA detectable. (C and D) Comparison of the $\alpha 6$ - and $\beta 4$-subunits of CHRN expression in testicular capsule (TC) and testicular parenchyma (TP). The $\Delta C_{\mathrm{t}}$ values were subtracted from 50 showing higher values with higher expression. samples. It was found at lower levels in TC and parenchyma of 16-day-old animals, whereas adult rats showed extremely high ACh levels in the parenchyma $(3068.3 \pm 764.94$ vs $3.8 \pm 1.62 \mathrm{pmol} / \mathrm{mg}$ protein, Table 2 and Fig. 7) and the ACh levels were similar in adults and 16-day-old rats in the capsule. Freshly isolated germ cells of adult rats also contained ACh; however, significantly higher levels were present in the supernatant $(11.24 \pm 3.65$ vs $47.74 \pm 23.79 \mathrm{pmol} / \mathrm{mg}$ protein, Table 2 and Fig. 7).

\section{Discussion}

\section{ACh synthesising enzyme and transporters are present in $T P$}

This study demonstrates that non-neuronal cells in the parenchyma of rat testis have all the components necessary for cholinergic signalling. We detected mRNAs for the ACh synthesising enzyme, transporters and ACh receptors in locations completely lacking any form of innervation as was demonstrated by the absence of PGP 9.5 labelling (see also Zhu et al. (1995)).

\section{Cells of the germinal epithelium can synthesise ACh}

Previous studies have demonstrated Chat mRNA and activity in human and rat spermatozoa (Sastry et al. 1981, Ibanez et al. 1991), while the ACh degrading enzyme ACh esterase, $A C h E$, is expressed in rat spermatozoa with higher enzymatic activity in testis than in epididymis (Egbunike 1980). We now have found CHAT and SLC5A7 mRNAs and proteins in isolated germ cells in vitro as well as in situ. In addition, mRNAs for two cholinergic transporters, Slc18a3 and Slc22a2, were present in isolated spermatocytes and spermatids. SLC5A7 is the rate-limiting factor in ACh synthesis (Ribeiro et al. 2006), whereas SLC18A3 and SLC22A2 are involved in vesicular and non-vesicular ACh release respectively (Erickson et al. 1996, Ribeiro et al. 2006). Taken together, these observations strongly support the possibility that the germinal epithelium has the capability to synthesise and release ACh. However, it cannot be excluded that the testicular ACh synthesising machinery is not functional. Lonnerberg \& Ibanez (1999) described truncated non-functional forms of CHAT in rat testis. Our expression analysis demonstrated the presence of mRNA and protein for ACh synthesis, and data are supported by the detection of ACh in rat testis and in isolated germ cells. ACh was present in isolated cells at about $11 \mathrm{pmol} / \mathrm{mg}$ protein and at higher levels of about $48 \mathrm{pmol} / \mathrm{mg}$ protein in the supernatant. The levels are comparable to the ACh content determined in non-neuronal cells. ACh concentrations in mononuclear cells were $0.35 \mathrm{pmol} / 1$ million cells (Fujii \& Kawashima 2001), $1.21 \mathrm{pmol} / 1$ million cells (Innis 2011) and $0.83 \mathrm{pmol} / 1$ million cells (Hecker et al. 


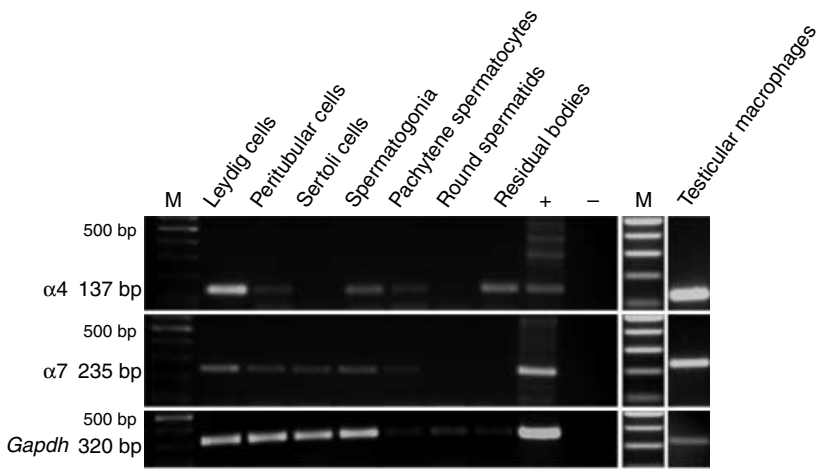

Figure 5 The presence of nicotinic ACh receptor $(\mathrm{CHRN})$ subunits $\alpha 4$ (product length $137 \mathrm{bp}$ ) and $\alpha 7$ (product length $235 \mathrm{bp}$ ) was determined in isolated testicular cell populations using RT-PCR. Gapdh (product length $320 \mathrm{bp}$ ) served as the reference gene.

+ , positive control rat brain; -, negative water control; $M$, marker.

2009). In the absence of nerve fibres, our results clearly indicate a local non-neuronal source of ACh in rat testis. The two interesting observations in this study are the high ACh levels in the supernatant of germ cells and the strong increase in ACh levels in adult rat testis. The high level in the supernatant of freshly isolated germ cells may be related to constant $\mathrm{ACh}$ synthesis and release from the germ cells itself. This is supported by the fact that the molecule responsible for storage of ACh, SLC18A3, could not be detected in the germ cell population. This is similar to human and murine leukocytes and crypt cells in the distal rat colon, which also do not express SLC18A3, but contains or synthesises ACh (Kawashima \& Fujii 2000, Yajima et al. 2010). In addition, vascular endothelial cells, TM and Sertoli cells could also be a potential source of endogenous ACh. Endothelial cells have been shown to contain the machinery responsible for ACh and release ACh (Haberberger et al. 2000, Kirkpatrick et al. 2003), and macrophages and Sertoli cells express Chat and Slc5a7 mRNA. These cells could synthesise and release $\mathrm{ACh}$ in the absence of a functional ACh synthesis in germ cells.

\section{Testicular cells can be targets for non-neuronal ACh}

The TP contains a large variety of potential targets for non-neuronally released ACh. We found the mRNA for eight $\alpha$ and three $\beta$-subunits of CHRN in testicular cells, including mRNAs for the supposedly 'muscle specific' $\alpha 1-$ and $\beta 1$-subunits. These subunits are also expressed in human skin, where their function remains elusive (Spies et al. 2006). Expression of the $\alpha 7$-subunit of CHRN was widespread in spermatogonia, spermatocytes within seminiferous tubules as well as within Sertoli cells. Spermatogonia and spermatocytes also expressed the $\alpha 4$-subunit of CHRN, potentially as part of the heteropentameric $\alpha 4 \beta 2 \mathrm{CHRN}$, which is one of the major CHRN subtypes in neuronal tissue (Albuquerque et al. 2009).

The adverse effects of smoking on reproductive function such as preterm delivery and abortion are well established. In the male, nicotine, a major component of cigarette smoke, induced impairment of spermatogenesis and steroidogenesis, the latter probably by affecting steroidogenic acute regulatory protein (StAR), the ratelimiting factor in sex steroid synthesis (Gocze \& Freeman 2000, Bose et al. 2007). However, the identification of the mRNAs for at least the $\alpha 4$ - and $\alpha 7$-subunits of CHRN in Leydig cells in this study proposes an additional mechanism of suppression of androgen production. Effects on spermatogenesis and sperm function parameters can be explained by the presence of $\alpha 3-, \alpha 5-$, $\alpha 7-, \alpha 9-$ and $\beta 4$-subunits of CHRN in ejaculated human spermatozoa, which are indicative of an earlier production during germ cell development in the testis, a finding that is partially supported by our mRNA expression data. Functionally, mouse sperm deficient of the $\alpha 7$-subunit of CHRN shows impaired motility (Bray et al. 2005) and the ACh-triggered acrosome
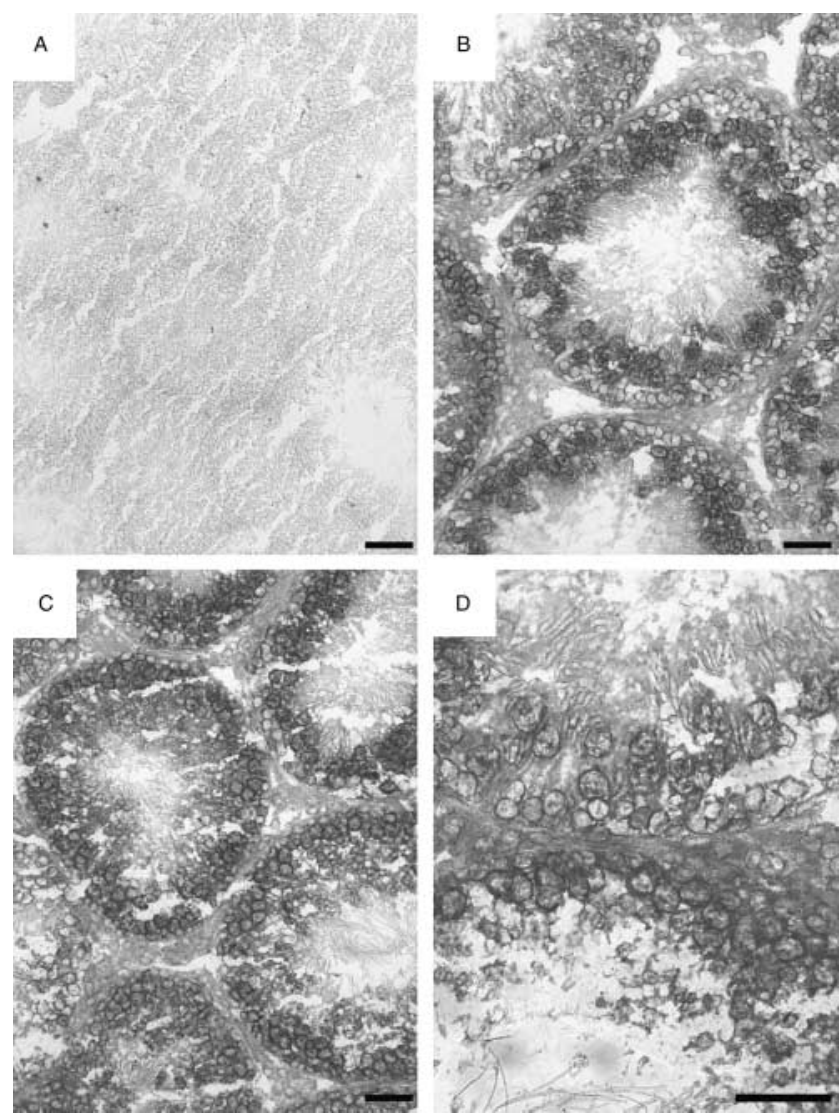

Figure 6 Localisation of $\alpha 7$-subunit of CHRN mRNA expression was examined in rat testis using in situ hybridisation. (A) Sense and (B-D) antisense probes. Staining for the $\alpha 7$-subunit of CHRN mRNA was mainly visible in primary spermatocytes, with only few round spermatids weakly labelled. Interstitial cells were negative. No staining was obtained using the sense probe (A). Bars, $20 \mu \mathrm{m}$. 
Table 2 Acetylcholine content in germ cell preparations and testicular capsule (TC) and testicular parenchyma (TP).

\begin{tabular}{lcccc}
\hline Source & $\begin{array}{c}\text { Samples } \\
(n)\end{array}$ & $\begin{array}{c}\text { Ratio }(\%) \\
\text { ACh/choline }\end{array}$ & $\begin{array}{c}\text { Protein } \\
(\mu \mathrm{g} / \mathrm{ml})\end{array}$ & $\begin{array}{c}\text { ACh }(\mathrm{pmol} / \mathrm{mg} \\
\text { protein })\end{array}$ \\
\hline Germ cells & 5 & 67 & 425.00 & $11.24 \pm 3.65$ \\
Germ cells & 6 & 200 & 841.67 & $47.74 \pm 23.79$ \\
$\quad$ supernatant & & & & \\
TC d16 & 6 & 36 & 666.67 & $6.33 \pm 2.41$ \\
TP d16 & 6 & 08 & 1662.50 & $3.61 \pm 1.32$ \\
TC adult & 2 & 18 & 5850.00 & $3.8 \pm 1.62$ \\
TP adult & 2 & 45 & 212.50 & $3068.3 \pm 764.94$ \\
\hline
\end{tabular}

reaction was suppressed by antagonists of tyrosine phosphorylation (Kumar \& Meizel 2005). Other CHRN subunits seem to have no direct impact on fertility since mice with deficiency in the subunits $\alpha 4, \beta 2$ (Marubio et al. 1999), $\alpha 5$ (Wang et al. 2002) and $\beta 4$ (Wang et al. 2003) were reported with no abnormalities with respect to litter size and fertility. As spermatozoa are exclusively transported in the luminal compartment of the male and female reproductive tract separated by epithelial cells from nerve endings that could release ACh, the studies of Bray et al. (2005) and Kumar \& Meizel (2005) are a clear indication for the necessity of a non-neuronal cholinergic system in the male gonad and during fertilisation.

Albeit information from toxicological studies and transgenic mouse models have provided some insight in the pathophysiological functions of the cholinergic system, its role in the normal testis is still unclear. Observations from other systems suggest that CHRN can mediate effects on cell division, metabolism and motility also in testicular tissue. The proximity of cellular ACh synthesising and reception sites in the testis favours an autocrine or paracrine mode of regulating testicular function by the non-neuronal cholinergic system, comparable to what is observed in the lymphatic system and the skin (Kawashima \& Fujii 2000, Kurzen et al. 2007). Taken together, our results are a clear indication for a functional non-neuronal cholinergic system in the testis and add important data to further understand the pathophysiological consequences of smoking on male reproductive function.

\section{Materials and Methods}

\section{Tissue preparation}

Specimens for RT-PCR were obtained from 8- to 10-week-old male Wistar-Firth rats. The animals were killed by a lethal dose of isoflurane, and the testis was removed and decapsulated. Approximately $30 \mathrm{mg}$ TP and the complete capsule were snapfrozen separately in liquid nitrogen and stored at $-80^{\circ} \mathrm{C}$ until required. For in situ hybridisation, the testis was snap frozen in liquid isopentane and fixed as required after sectioning. For immunohistochemistry, TP and capsule were immersion fixed in Zamboni's fixative ( $2 \%$ formaldehyde, $15 \%$ picric acid in $0.2 \mathrm{M}$ phosphate buffer, $\mathrm{pH}$ 7), washed overnight in PBS, cryoprotected in $18 \%$ sucrose and frozen in optimal cutting temperature compound. All animal procedures were performed in accordance with approval from the Flinders University Animal Welfare Committee.

\section{Isolation of cells from the rat testis}

Leydig cells, Sertoli cells, spermatogonia, pachytene spermatocytes, round spermatids and residual bodies were prepared from rat testes as described previously (Guillaume et al. 2001). TM were isolated from testes without any enzymatic treatment. The testes were decapsulated into $10 \mathrm{ml}$ pre-warmed endotoxin-free DMEM-F12 medium (PAA Laboratories, Morningside, QLD, Australia). The seminiferous tubules were gently separated, and the volume was adjusted to $50 \mathrm{ml}$. After gentle stirring, the tubule fragments were allowed to settle for $5 \mathrm{~min}$ before the supernatant was centrifuged at $300 \mathrm{~g}$ for 10 min. The pellet containing interstitial cells and TM was resuspended in $5 \mathrm{ml} \mathrm{DMEM-F12}$ and incubated at $32{ }^{\circ} \mathrm{C}$ and $5 \% \mathrm{CO}_{2}$ for $30 \mathrm{~min}$. TM and the remaining interstitial cells were separated by the more rapid adherence of TM to surfaces.
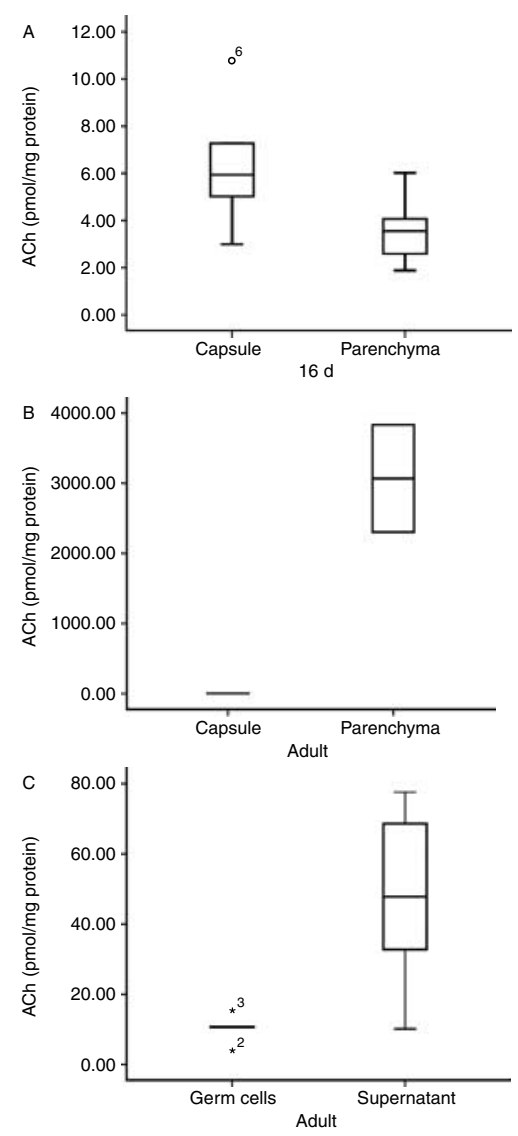

Figure 7 Detection of ACh in rat germ cells, testicular capsule and testicular parenchyma (A-C). Comparison of the ACh content in 16-day-old immature and adult testes showed that ACh was present at low levels in testicular capsule and testicular parenchyma of 16-day-old animals (A), while adult rats showed very high ACh levels in the parenchyma and low levels in the capsule (B). The box plots in $\mathrm{C}$ show the presence of $\mathrm{ACh}$ in freshly isolated germ cells and in the supernatant. 
After 30 min, non-adherent cells were removed by washing with fresh medium. Subsequently, TM were washed a second time, by pipetting directly on the surface. Purity of TM $(80 \%)$ was determined by immunolabelling using monoclonal antibodies ED1 and ED2 (AbD Serotec, Oxford, UK) directed against monocytes/macrophages.

\section{RT-PCR}

RT-PCR was used to detect mRNAs in isolated populations of testicular cells (PTC 200; Peqlab, Erlangen, Germany). Quantitative real-time PCR (RT-qPCR) was used to quantify relative expression levels of mRNAs using CDNA from TP and capsule (Corbett Roto-cycler, Sydney, NSW, Australia). Capsule and parenchyma were lysed in RLT lysis buffer (Qiagen) using a tissue lyser (Qiagen). RNA was extracted (RNeasy Mini Kit,
Qiagen), and quantity and quality of the RNA were determined. Isolated testicular cells were lysed in RLT buffer, homogenised with a $21 \mathrm{G}$ syringe and subsequently used for RNA extraction according to the manufacturer's instructions (RNeasy Mini Kit, Qiagen). Total RNA from brain served as positive control. In negative controls, the reverse transcriptase was replaced by water (negative water control). The extraction was followed by DNase digestion and RT (iScript, Bio-Rad). The cDNA was used for subsequent PCR and RT-qPCR. RT-PCR for isolated testicular cells was performed as for standard PCR in a $25 \mu \mathrm{l}$ reaction volume with $1 \mu \mathrm{l}$ cDNA, $0.2 \mathrm{mM}$ dNTP mix, $1 \mathrm{mM} \mathrm{MgCl}_{2}, 0.2$ pmol each primer (Table 3), buffer and GoTaq Polymerase according to the manufacturer's protocol (Promega). Gapdh was used as the reference gene. All RT-qPCR were performed in duplicate or triplicate from three to six animals using a ready-to-use kit according to the

Table 3 Primer pairs used for RT-PCR.

\begin{tabular}{|c|c|c|c|c|}
\hline \multirow{3}{*}{$\frac{\text { Primer }}{\text { Chat }}$} & \multicolumn{2}{|c|}{ Sequence $\left(5^{\prime} \rightarrow 3^{\prime}\right) \mathrm{F}-$ forward and $\mathrm{R}-$ reverse } & \multirow{2}{*}{$\begin{array}{l}\text { Product length }(b p) \\
272\end{array}$} & \multirow{2}{*}{$\frac{\text { Accession no. }}{\text { XM_224626 }}$} \\
\hline & $\mathrm{F}$ & TGAACGCCTGССТCСАTTCGGССTGCTGA & & \\
\hline & $\mathrm{R}$ & GTGCCATCTCGGCCCACCACGAACTGCA & & \\
\hline \multirow[t]{2}{*}{ Chat } & $\mathrm{F}$ & CAACCATCTTCTGGCACTGA & 183 & XM 224626 \\
\hline & $\mathrm{R}$ & TAGCAGGCTCAATAGCCATT & & \\
\hline \multirow[t]{2}{*}{ Slc18a3 } & $\mathrm{F}$ & GCCACATCGTTCACTCTCTTG & 149 & X80395 \\
\hline & $\mathrm{R}$ & CGGTTCATCAAGCAACACATC & & \\
\hline \multirow[t]{2}{*}{ Slc22a2 } & $\mathrm{F}$ & GССТССТGАТССТGGСТG & 226 & X98334 \\
\hline & $\mathrm{R}$ & GGTGTCAGGTTCTGAAGAGAG & & \\
\hline \multirow[t]{2}{*}{ Slc5a7 } & $\mathrm{F}$ & ATGGCTCTACCAGCCATTTG & 189 & AB030947.1 \\
\hline & R & GGACATGACAGCAGCAGAAA & & \\
\hline \multirow{2}{*}{ Slc5a7 } & $\mathrm{F}$ & CAAGACCAAGGAGGAAGCAC & 150 & AB030947.1 \\
\hline & $\mathrm{R}$ & GCAAACATGGAACTTGTCGA & & \\
\hline \multirow[t]{2}{*}{ Rp/19 } & $\mathrm{F}$ & CATGGAGCACATCCACAAAC & 216 & NM_031103.1 \\
\hline & $\mathrm{R}$ & CCATAGCCTGGCCACTATGT & & \\
\hline \multirow[t]{2}{*}{$18 S$ rRNA } & $\mathrm{F}$ & CCGCAGCTAGGAATAATGGA & 245 & M11188 \\
\hline & $\mathrm{R}$ & AGTCGGCATCGTTTATGGTC & & \\
\hline \multirow[t]{2}{*}{ Gapdh } & $\mathrm{F}$ & CATTGTTGCCATCAACGACC & 320 & NM_017008 \\
\hline & $\mathrm{R}$ & TCACACCCATCACAAACATG & & \\
\hline \multirow[t]{2}{*}{$\alpha 1$} & $\mathrm{~F}$ & ААCTTCATGGAGAGCGGAGA & 285 & NM_024485.1 \\
\hline & $\mathrm{R}$ & САGСТССАСААТGАСGАGAА & & \\
\hline \multirow[t]{2}{*}{$\alpha 2$} & $\mathrm{~F}$ & GGAGCAGATGGAGAGGACAG & 216 & NM_133420.1 \\
\hline & R & AGCACAGTGAGGCAGGAGAT & & \\
\hline \multirow[t]{2}{*}{$\alpha 3$} & $\mathrm{~F}$ & GCCAACСТCACAAGAAGCTC & 208 & NM_052805.2 \\
\hline & $\mathrm{R}$ & CCAGGATGAAAACCCAGAGA & & \\
\hline \multirow[t]{2}{*}{$\alpha 4$} & $\mathrm{~F}$ & GGACССТGGTGACTACGAGA & 137 & NM_024354 \\
\hline & $\mathrm{R}$ & CATAGAACAGGTGGGCCTTG & & \\
\hline \multirow[t]{2}{*}{$\alpha 5$} & $\mathrm{~F}$ & CACGTCGTGAAAGAGAACGA & 112 & NM_017078.2 \\
\hline & $\mathrm{R}$ & TCCCAATGATTGACACCAGA & & \\
\hline \multirow[t]{2}{*}{$\alpha 6$} & $\mathrm{~F}$ & ACAGCTCTTCCACACGCTCT & 286 & NM 057184.1 \\
\hline & $\mathrm{R}$ & GAAGTCACCGACGGCATTAT & & \\
\hline \multirow[t]{2}{*}{$\alpha 7$} & $\mathrm{~F}$ & GGCTCTGCTGGTATTCTTGC & 286 & NM_012832.3 \\
\hline & $\mathrm{R}$ & AAACCATGCACACCAGTTCA & & \\
\hline \multirow[t]{2}{*}{$\alpha 7$} & $\mathrm{~F}$ & ACATTGACGTTCGCTGGTTC & 235 & L31619 \\
\hline & $\mathrm{R}$ & CTACGGCGCATGGTTACTGT & & \\
\hline \multirow[t]{2}{*}{$\alpha 9$} & $\mathrm{~F}$ & CGTGGGATCGAGACCAGTAT & 242 & NM_022930.1 \\
\hline & $\mathrm{R}$ & AAAGGTCAGGTTGCACTGCT & & \\
\hline \multirow[t]{2}{*}{$\alpha 10$} & $\mathrm{~F}$ & СTGCTGACTCTGGGGAGAAG & 317 & NM_022639.1 \\
\hline & $\mathrm{R}$ & GGCTGACTCTAGTGGCTTGG & & \\
\hline \multirow[t]{2}{*}{$\beta 1$} & $\mathrm{~F}$ & CATCGAGTCTCTCCGTGTCA & 206 & NM 012528.1 \\
\hline & $\mathrm{R}$ & TGCAATTCTGCCAGTCAAAG & & \\
\hline$\beta 2$ & $\mathrm{~F}$ & AAGCCTGAGGACTTCGACAA & 142 & NM_019297.1 \\
\hline & $\mathrm{R}$ & TGCCATCATAGGAGACCACA & & \\
\hline$\beta 3$ & $\mathrm{~F}$ & САСТСТGСGСТTGAAAGGAA & 196 & NM_133597.1 \\
\hline & $\mathrm{R}$ & GCGGACCCATTTCTGGTAAC & & \\
\hline$\beta 4$ & $\mathrm{~F}$ & СТССТGAACAAAACCCGGTA & 371 & NM_052806.2 \\
\hline & $\mathrm{R}$ & ACCTCAATCTTGCAGGCACT & & \\
\hline
\end{tabular}


Table 4 Primer used for generation of in situ hybridisation probes. T7 binding site TAATACGACTCACTATAGGG; SP6 binding site ATTTAGGTGACACTATAGAA.

\begin{tabular}{|c|c|c|}
\hline Primer & Sequence $\left(5^{\prime} \rightarrow 3^{\prime}\right) \mathrm{F}$ - forward, $\mathrm{R}$ - reverse & Product length $(b p)$ \\
\hline Chat_F & TAATACGACTCACTATAGGGTGAACGССТGССТССАTTCGGССТGCTGA & 312 \\
\hline Chat $R$ & ATTTAGGTGACACTATAGAAGTGCCATCTCGGCCCACCACGAACTGCA & \\
\hline$\alpha 7 \_F$ & TAATACGACTCACTATAGGGGGCTCTGCTGGTATTCTTGC & 326 \\
\hline$\alpha 7 \_R$ & ATTTAGGTGACACTATAGAAAAACCATGCACACCAGTTCA & \\
\hline
\end{tabular}

manufacturer's protocol (iQ SYBR green Supermix, BioRad). Primers specific for mRNA sequences were designed using Blast (http://www.ncbi.nlm.nih.gov/tools/primer-blast/) (Table 3). All primers spanned introns except the primers for the $\alpha 2$-subunit and Slc18a3. All PCR products were sequenced (Flinders University Sequencing Facility) and showed $100 \%$ homology with the predicted target sequence. Primers specific for the rat reference genes Rp/19 (Adams et al. 2007) and $18 S$ rRNA were used for normalisation. The RT-qPCR data were normalised by subtracting the threshold cycle $\left(C_{\mathrm{T}}\right)$ levels between the genes of interest and the mean of Rp/19 and $18 S$ rRNA (Livak \& Schmittgen 2001). The $\Delta C_{\mathrm{T}}$ values were subtracted from 50 so that higher values reflect higher expression levels.

\section{In situ hybridisation}

In situ hybridisation probes were prepared using digoxigenin (DIG) labelling (Roche). The primers contained binding sites for either the T7 or SP6 RNA polymerase (Table 4). Cryosections $(12 \mu \mathrm{m})$ were fixed in $4 \%$ paraformaldehyde (PFA), permeabilised with proteinase $\mathrm{K}(2 \mu \mathrm{g} / \mathrm{ml})$ for $7 \mathrm{~min}$, fixed again in PFA and acetylated $(0.1 \mathrm{M}$ triethanolamine containing $0.25 \%(\mathrm{v} / \mathrm{v})$ acetic anhydride). After prehybridisation, hybridisation was performed overnight at $65^{\circ} \mathrm{C}$. Subsequently, the sections were washed in decreasing concentrations of SSC. The DIG-labelled probes were detected using alkaline phosphate-conjugated anti-DIG antibody and subsequent visualisation using NBT/ BCIP as substrate (Roche). Colour development was allowed to proceed in the darkness for $4-16 \mathrm{~h}$. The reaction was terminated by immersion in tap water.

\section{Immunohistochemistry}

Rat testes were serially cryosectioned at a thickness of $12 \mu \mathrm{m}$, fixed with methanol and subsequently preincubated for $1 \mathrm{~h}$ with PBS (145.4 mM NaCl (8.5 g/l), $7.54 \mathrm{mM} \mathrm{Na}{ }_{2} \mathrm{HPO}_{4}$ (1.07 g/l), $\left.2.5 \mathrm{mM} \mathrm{NaH}_{2} \mathrm{PO}_{4} \mathrm{H}_{2} \mathrm{O}(0.39 \mathrm{~g} / \mathrm{l}), \mathrm{pH} 7.1\right)$ containing $10 \%$ normal donkey serum, $0.1 \%$ BSA and $0.5 \%$ Tween 20 . Indirect immunofluorescence was performed by overnight incubation with antisera directed against either PGP 9.5, CHAT, SLC5A7 or SLC18A3 in combination with an FITCconjugated anti-smooth muscle actin antibody (anti-SMAFITC; Table 5) diluted in PBS with doubled concentration $\mathrm{NaCl}$ at room temperature followed by washing in PBS and subsequent incubation with appropriate combinations of secondary reagents (Table 5) for $1 \mathrm{~h}$ at room temperature. After incubation with the secondary reagents, the slides were washed in PBS and coverslipped in carbonate-buffered glycerol at $\mathrm{pH} 8.6$ and evaluated by fluorescence microscopy or sequential scanning using a confocal laser scanning microscope (TCS SP5, Leica, Bensheim, Germany). Specificity of the CHAT, SLC18A3 and SLC22A2 antisera was tested by pre-absorption with the corresponding antigen. In addition, the specificity of the SLC5A7 antibody has been shown in murine cochlea, brain and spinal cord (SLC5A7, Brandon et al. 2004, Bergeron et al. 2005).

\section{ACh measurement}

Freshly prepared tissue from testes was homogenised in ten volumes of a mixture of ice-cold acetone (85\%) and $1 \mathrm{M}$ formic acid (15\%) as described previously (Klein et al. 1993). Cultured cells and cell media (supernatant) were taken in 96\% ethanol. Homogenates were centrifuged at $10000 \mathrm{~g}$. Aliquots of the supernatant were taken to dryness in a vacuum centrifuge, taken in HPLC buffer and injected into a Eicom HTEC-500 microbore system coupled to a Shimadzu SIL-20AC autosampler. The buffer composition was $5 \mathrm{~g} \mathrm{KHCO}_{3}, 400 \mathrm{mg}$ sodium decanesulfonate, and $50 \mathrm{mg}$ EDTA in $1 \mathrm{I}$ Aqua Dest. ( $\mathrm{pH} 8.3$ ). At a flow rate of $0.15 \mathrm{ml} / 7 \mathrm{~min}$, retention times were $7.8 \mathrm{~min}$ for choline and $13.2 \mathrm{~min}$ for ACh. The limit of detection was 1-2 fmol analyte per $5 \mu \mathrm{l}$ injection volume. ACh chloride and choline chloride (purity $>99 \%$ each) were purchased from Sigma-Aldrich.

Table 5 Primary and secondary antisera, nuclear staining.

\begin{tabular}{|c|c|c|c|c|}
\hline Antibody & Host & Conjugate & Supplier & Dilution \\
\hline \multicolumn{5}{|l|}{ Primary } \\
\hline Anti-rat-SLC5A7 & $\begin{array}{c}\text { Polyclonal, } \\
\text { rabbit }\end{array}$ & & Chemicon & $1: 100$ \\
\hline Anti-rat-CHAT & $\begin{array}{c}\text { Polyclonal, } \\
\text { sheep }\end{array}$ & & Chemicon & $1: 2000$ \\
\hline Anti-rat-SLC18A3 & $\begin{array}{l}\text { Polyclonal, } \\
\text { goat }\end{array}$ & & Chemicon & $1: 800$ \\
\hline Anti-SMA & $\begin{array}{l}\text { Monoclonal, } \\
\text { mouse }\end{array}$ & FITC & Sigma & $1: 800$ \\
\hline Anti-rat-PGP 9.5 & $\begin{array}{l}\text { Polyclonal, } \\
\text { rabbit }\end{array}$ & & Neuromics & $1: 500$ \\
\hline \multicolumn{5}{|l|}{ Secondary } \\
\hline Anti-rabbit-Ig & Donkey & Cy3 & Jackson & $1: 100$ \\
\hline Anti-sheep/goat-Ig & Donkey & Сy3 & Jackson & $1: 100$ \\
\hline Hoechst 333258 & & & Mol. Probes & $1: 2000$ \\
\hline
\end{tabular}

Chemicon, Boronia, Australia; Neuromics, Medina, MN, USA; Jackson Immuno Research, West Grove, PA, USA; Molecular Probes (Invitrogen), Mulgrave, VIC, Australia. 


\section{Declaration of interest}

The authors declare that there is no conflict of interest that could be perceived as prejudicing the impartiality of the research reported.

\section{Funding}

This work was supported by the Else Kröner-Fresenius-Stiftung and the Flinders University Mary Overton Neuroscience Fellowship.

\section{Acknowledgements}

The grant support of the Else Kröner-Fresenius-Stiftung and a travel grant of the DAAD are gratefully acknowledged. The helpful assistance of Sudhanshu Bhushan, Eva Schneider und Yongning Lu is gratefully acknowledged.

\section{References}

Adams V, Linke A, Wisloff U, Doring C, Erbs S, Krankel N, Witt CC, Labeit S, Muller-Werdan U, Schuler G et al. 2007 Myocardial expression of Murf-1 and MAFbx after induction of chronic heart failure: effect on myocardial contractility. Cardiovascular Research 73 120-129. (doi:10. 1016/j.cardiores.2006.10.026)

Albuquerque EX, Pereira EF, Alkondon M \& Rogers SW 2009 Mammalian nicotinic acetylcholine receptors: from structure to function. Physiological Reviews 89 73-120. (doi:10.1152/physrev.00015.2008)

Bergeron AL, Schrader A, Yang D, Osman AA \& Simmons DD 2005 The final stage of cholinergic differentiation occurs below inner hair cells during development of the rodent cochlea. Journal of the Association for Research in Otolaryngology 6 401-415. (doi:10.1007/s10162-0050018-3)

Borges MO, Abreu ML, Porto CS \& Avellar MC 2001 Characterization of muscarinic acetylcholine receptor in rat Sertoli cells. Endocrinology 142 4701-4710. (doi:10.1210/en.142.11.4701)

Bose M, Debnath D, Chen Y \& Bose HS 2007 Folding, activity and import of steroidogenic acute regulatory protein into mitochondria changed by nicotine exposure. Journal of Molecular Endocrinology 39 67-79. (doi:10.1677/JME-07-0051)

Brandon EP, Mellott T, Pizzo DP, Coufal N, D'Amour KA, Gobeske K, Lortie M, Lopez-Coviella I, Berse B, Gage FH et al. 2004 Choline transporter 1 maintains cholinergic function in choline acetyltransferase haploinsufficiency. Journal of Neuroscience 24 5459-5466. (doi:10. 1523/JNEUROSCI.1106-04.2004)

Bray C, Son JH, Kumar P \& Meizel S 2005 Mice deficient in CHRNA7, a subunit of the nicotinic acetylcholine receptor, produce sperm with impaired motility. Biology of Reproduction 73 807-814. (doi:10.1095/ biolreprod.105.042184)

Dwivedi C \& Long NJ 1989 Effect of cholinergic agents on human spermatozoa motility. Biochemical Medicine and Metabolic Biology 42 66-70. (doi:10.1016/0885-4505(89)90042-X)

Egbunike GN 1980 Changes in acetylcholinesterase activity of mammalian spermatozoa during maturation. International Journal of Andrology 3 459-468. (doi:10.1111/j.1365-2605.1980.tb00134.x)

Erickson JD, Weihe E, Schafer MK, Neale E, Williamson L, Bonner TI, TaoCheng JH \& Eiden LE 1996 The VAChT/ChAT, "cholinergic gene locus": new aspects of genetic and vesicular regulation of cholinergic function. Progress in Brain Research 109 69-82. (doi:10.1016/S0079-6123(08) 62089-0)

Fujii T \& Kawashima K 2001 An independent non-neuronal cholinergic system in lymphocytes. Japanese Journal of Pharmacology 85 11-15. (doi:10.1254/jjp.85.11)

Fujii T, Takada-Takatori Y \& Kawashima K 2008 Basic and clinical aspects of non-neuronal acetylcholine: expression of an independent, non-neuronal cholinergic system in lymphocytes and its clinical significance in immunotherapy. Journal of Pharmacological Sciences 106 186-192. (doi:10.1254/jphs.FM0070109)

Gocze PM \& Freeman DA 2000 Cytotoxic effects of cigarette smoke alkaloids inhibit the progesterone production and cell growth of cultured MA-10 Leydig tumor cells. European Journal of Obstetrics, Gynecology, and Reproductive Biology 93 77-83. (doi:10.1016/S0301-2115(00) 00254-2)

Grando SA, Kawashima K \& Wessler I 2003 Introduction: the non-neuronal cholinergic system in humans. Life Sciences 72 2009-2012. (doi:10. 1016/S0024-3205(03)00063-8)

Grozio A, Catassi A, Cavalieri Z, Paleari L, Cesario A \& Russo P 2007 Nicotine, lung and cancer. Anti-Cancer Agents in Medicinal Chemistry 7 461-466. (doi:10.2174/187152007781058587)

Guillaume E, Pineau C, Evrard B, Dupaix A, Moertz E, Sanchez JC, Hochstrasser DF \& Jegou B 2001 Cellular distribution of translationally controlled tumor protein in rat and human testes. Proteomics 1 880-889. (doi:10.1002/1615-9861(200107) 1:7 <880::AID-PROT880>3.0.CO;2-2)

Haberberger RV, Bodenbenner M \& Kummer W 2000 Expression of the cholinergic gene locus in pulmonary arterial endothelial cells. Histochemistry and Cell Biology 113 379-387. (doi:10.1007/s00418 0000153)

Hecker A, Mikulski Z, Lips KS, Pfeil U, Zakrzewicz A, Wilker S, Hartmann P, Padberg W, Wessler I, Kummer W et al. 2009 Pivotal advance: up-regulation of acetylcholine synthesis and paracrine cholinergic signaling in intravascular transplant leukocytes during rejection of rat renal allografts. Journal of Leukocyte Biology 86 13-22. (doi:10.1189/jlb.1107722)

Herber DL, Severance EG, Cuevas J, Morgan D \& Gordon MN 2004 Biochemical and histochemical evidence of nonspecific binding of $\alpha 7 \mathrm{nAChR}$ antibodies to mouse brain tissue. Journal of Histochemistry and Cytochemistry 52 1367-1376. (doi:10.1177/002215540405201013)

Ibanez CF, Pelto-Huikko M, Soder O, Ritzen EM, Hersh LB, Hokfelt T \& Persson H 1991 Expression of choline acetyltransferase mRNA in spermatogenic cells results in an accumulation of the enzyme in the postacrosomal region of mature spermatozoa. PNAS 88 3676-3680. (doi:10.1073/pnas.88.9.3676)

Innis SM, Davidson AG, Bay BN, Slack PJ \& Hasman D 2011 Plasma choline depletion is associated with decreased peripheral blood leukocyte acetylcholine in children with cystic fibrosis. American Journal of Clinical Nutrition 93 564-568. (doi:10.3945/ajcn.110.005413)

Kawashima K \& Fujii T 2000 Extraneuronal cholinergic system in lymphocytes. Pharmacology \& Therapeutics 86 29-48. (doi:10.1016/ S0163-7258(99)00071-6)

Kirkpatrick CJ, Bittinger F, Nozadze K \& Wessler I 2003 Expression and function of the non-neuronal cholinergic system in endothelial cells. Life Sciences 72 2111-2116. (doi:10.1016/S0024-3205(03)00069-9)

Klein J, Gonzalez R, Köppen A \& Löffelholz K 1993 Free choline and choline metabolites in rat brain and body fluids: sensitive determination and implications for choline supply to the brain. Neurochemistry International 22 293-300. (doi:10.1016/0197-0186(93)90058-D)

Kumar P \& Meizel S 2005 Nicotinic acetylcholine receptor subunits and associated proteins in human sperm. Journal of Biological Chemistry 280 25928-25935. (doi:10.1074/jbc.M502435200)

Kummer W, Lips KS \& Pfeil U 2008 The epithelial cholinergic system of the airways. Histochemistry and Cell Biology 130 219-234. (doi:10.1007/ s00418-008-0455-2)

Kurzen H, Wessler I, Kirkpatrick CJ, Kawashima K \& Grando SA 2007 The non-neuronal cholinergic system of human skin. Hormone and Metabolic Research 39 125-135. (doi:10.1055/s-2007-961816)

Lips KS, Volk C, Schmitt BM, Pfeil U, Arndt P, Miska D, Ermert L, Kummer W \& Koepsell H 2005 Polyspecific cation transporters mediate luminal release of acetylcholine from bronchial epithelium. American Journal of Respiratory Cell and Molecular Biology 33 79-88. (doi:10. $1165 / \mathrm{rcmb} .2004-0363$ OC)

Livak KJ \& Schmittgen TD 2001 Analysis of relative gene expression data using real-time quantitative PCR and the $2(-$ Delta Delta $C(\mathrm{~T}))$ method. Methods 25 402-408. (doi:10.1006/meth.2001.1262)

Lonnerberg P \& Ibanez CF 1999 Novel, testis-specific mRNA transcripts encoding $\mathrm{N}$-terminally truncated choline acetyltransferase. Molecular Reproduction and Development 53 274-281. (doi:10.1002/(SICI)10982795(199907)53:3 <274::AID-MRD3 > 3.0.CO;2-8) 
Marubio LM, del Mar Arroyo-Jimenez M, Cordero-Erausquin M, Léna C, Le Novère $N$, de Kerchove d'Exaerde $A$, Huchet $M$, Damaj MI \& Changeux JP 1999 Reduced antinociception in mice lacking neuronal nicotinic receptor subunits. Nature 398 805-810. (doi:10.1038/19756)

Moser N, Mechawar N, Jones I, Gochberg-Sarver A, Orr-Urtreger A, Plomann M, Salas R, Molles B, Marubio L, Roth U et al. 2007 Evaluating the suitability of nicotinic acetylcholine receptor antibodies for standard immunodetection procedures. Journal of Neurochemistry 102 479-492. (doi:10.1111/j.1471-4159.2007.04498.x)

Nathanson NM 2008 Synthesis, trafficking, and localization of muscarinic acetylcholine receptors. Pharmacology \& Therapeutics 119 33-43. (doi:10.1016/j.pharmthera.2008.04.006)

Okuda T, Haga T, Kanai Y, Endou H, Ishihara T \& Katsura I 2000 Identification and characterization of the high-affinity choline transporter. Nature Neuroscience 3 120-125. (doi:10.1038/72059)

Paleari L, Sessa F, Catassi A, Servent D, Mourier G, Doria-Miglietta G, Ognio E, Cilli M, Dominioni L, Paolucci M et al. 2009 Inhibition of non-neuronal alpha7-nicotinic receptor reduces tumorigenicity in A549 NSCLC xenografts. International Journal of Cancer 125 199-211. (doi:10.1002/ijc.24299)

Parsons SM 2000 Transport mechanisms in acetylcholine and monoamine storage. FASEB Journal 14 2423-2434. (doi:10.1096/fj.000203rev)

Ribeiro FM, Black SA, Prado VF, Rylett RJ, Ferguson SS \& Prado MA 2006 The "ins" and "outs" of the high-affinity choline transporter ChT1. Journal of Neurochemistry 97 1-12. (doi:10.1111/j.1471-4159.2006. 03695.x)

Sastry BV, Janson VE \& Chaturvedi AK 1981 Inhibition of human sperm motility by inhibitors of choline acetyltransferase. Journal of Pharmacology and Experimental Therapeutics 216 378-384.

Spies M, Lips KS, Kurzen H, Kummer W \& Haberberger RV 2006 Nicotinic acetylcholine receptors containing subunits alpha3 and alpha5 in rat nociceptive dorsal root ganglion neurons. Journal of Molecular Neuroscience 30 55-56. (doi:10.1385/JMN:30:1:55)
Wang N, Orr-Urtreger A, Chapman J, Rabinowitz R, Nachman R \& Korczyn AD 2002 Autonomic function in mice lacking alpha5 neuronal nicotinic acetylcholine receptor subunit. Journal of Physiology $\mathbf{5 4 2}$ 347-354. (doi:10.1113/jphysiol.2001.013456)

Wang N, Orr-Urtreger A, Chapman J, Rabinowitz R \& Korczyn AD 2003 Deficiency of nicotinic acetylcholine receptor beta 4 subunit causes autonomic cardiac and intestinal dysfunction. Molecular Pharmacology 63 574-580. (doi:10.1124/mol.63.3.574)

Wessler I \& Kirkpatrick CJ 2008 Acetylcholine beyond neurons: the nonneuronal cholinergic system in humans. British Journal of Pharmacology 154 1558-1571. (doi:10.1038/bjp.2008.185)

Wessler I, Roth E, Deutsch C, Brockerhoff P, Bittinger F, Kirkpatrick CJ \& Kilbinger H 2001 Release of non-neuronal acetylcholine from the isolated human placenta is mediated by organic cation transporters. British Journal of Pharmacology 134 951-956. (doi:10.1038/sj.bjp. 0704335)

Yajima T, Inoue R, Matsumoto M \& Yajima M 2010 Non-neuronal release of ACh plays a key role in secretory response to luminal propionate in rat colon. Journal of Physiology 589 953-962. (doi:10.1113/jphysiol.2010. 199976)

Yamamoto Y, Isoyama E, Sofikitis N \& Miyagawa I 1998 Effects of smoking on testicular function and fertilizing potential in rats. Urological Research 26 45-48. (doi:10.1007/s002400050022)

Zhu BC, Chiocchio SR, Suburo AM \& Tramezzani JH 1995 Monoaminergic and peptidergic contributions of the superior and the inferior spermatic nerves to the innervation of the testis in the rat. Journal of Andrology $\mathbf{1 6}$ 248-258.

Received 9 July 2010

First decision 13 September 2010

Revised manuscript received 15 February 2011

Accepted 11 April 2011 